\title{
Chronic restraint stress induces changes in the cerebral Galpha 12/13 and Rho-GTPase signaling network
}

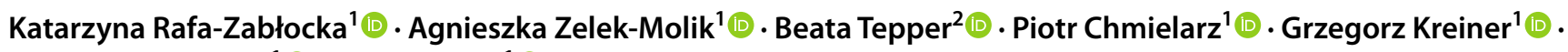 \\ Michał Wilczkowski ${ }^{1}$ (1) Irena Nalepa ${ }^{1}$ (i)
}

Received: 31 January 2021 / Revised: 28 May 2021 / Accepted: 1 June 2021 / Published online: 11 June 2021

(c) The Author(s) 2021

\begin{abstract}

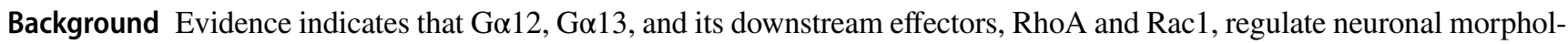
ogy affected by stress. This study was aimed at investigating whether repeated stress influences the expression of proteins related to the $\mathrm{G} \alpha 12 / 13$ intracellular signaling pathway in selected brain regions sensitive to the effects of stress. Furthermore, the therapeutic impact of $\beta(1)$ adrenergic receptors ( $\beta 1 \mathrm{AR})$ blockade was assessed.

Methods Restraint stress (RS) model in mice ( $2 \mathrm{~h} / 14$ days) was used to assess prolonged stress effects on the mRNA

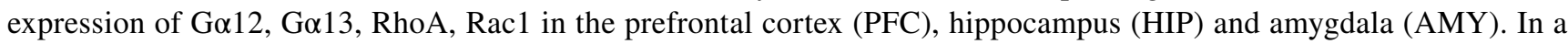
separate study, applying RS model in rats (3-4 h/1 day or 14 days), we evaluated stress effects on the expression of Go12, G 111 , G $\alpha$, RhoA, RhoB, RhoC, Rac1/2/3 in the HIP. Betaxolol (BET), a selective $\beta 1$ AR antagonist, was introduced (5 mg/ $\mathrm{kg} /$ p.o./8-14 days) in the rat RS model to assess the role of $\beta 1 \mathrm{AR}$ in stress effects. RT-qPCR and Western Blot were used for mRNA and protein assessments, respectively.

Results Chronic RS decreased mRNA expression of Go12 and increased mRNA for Rac1 in the PFC of mice. In the mice

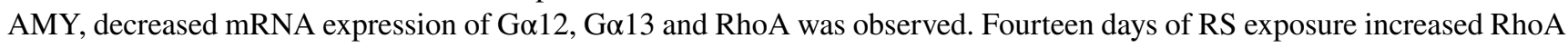
protein level in the rats' HIP in the manner dependent on $\beta 1$ AR activity.

Conclusions Together, these results suggest that repeated RS affects the expression of genes and proteins known to be engaged in neural plasticity, providing potential targets for further studies aimed at unraveling the molecular mechanisms of stress-related neuropsychiatric diseases.
\end{abstract}

Keywords Chronic stress · Galpha proteins · G-protein-coupled receptors · Mouse brain · Rat brain · Rho GTPases

$\begin{array}{ll}\text { Abbreviations } \\ \text { AMY } & \text { Amygdala } \\ \beta 1 \mathrm{AR} & \beta(1) \text { Adrenergic receptors } \\ \text { BET } & \text { Betaxolol } \\ \text { GTPase } & \text { Guanosine-5' triphosphatase } \\ \text { HIP } & \text { Hippocampus } \\ \text { 5-HT } & \text { Serotonin }\end{array}$

Katarzyna Rafa-Zabłocka and Agnieszka Zelek-Molik contributed equally to this work as co-first authors

Irena Nalepa

nfnalepa@cyf-kr.edu.pl

1 Department of Brain Biochemistry, Maj Institute of Pharmacology, Polish Academy of Sciences, Smętna 12, 31-343 Kraków, Poland

2 Laboratory of Calcium Binding Proteins, Nencki Institute of Experimental Biology, Polish Academy of Sciences, Pasteura 3, 02-093 Warsaw, Poland

$\begin{array}{ll}\text { PFC } & \text { Prefrontal cortex } \\ \text { po } & \text { Oral administration (lat. per os) } \\ \text { Rho protein } & \text { The Ras homologous (Rho) protein family } \\ \text { RS } & \text { Restraint stress } \\ \text { SEM } & \text { Standard error of mean }\end{array}$

\section{Introduction}

Excessive stress is considered an important etiological factor that can disturb the physiological integrity of the organism and contribute to various neuropsychiatric as well as neurodegenerative diseases $[1,2]$. The effects of excessive stress can be observed at various signal transduction levels, including changes in the synaptic level of neurotransmitters, their receptors, and intracellular proteins engaged in regulating neuronal activity and structure. Indeed, a growing body of evidence from various stress models indicates that repeated stress affects 
the brain's structural and functional plasticity [3]. Changes in plasticity are manifested by brain region-specific alterations in dendritic and synaptic structure [4-7].

Various central nervous system neurotransmitters involved in stress response modulation act through the metabotropic G-protein-coupled receptors (GPCR). The heterotrimeric $(\alpha \beta \gamma) \mathrm{G}$ proteins perform the role of molecular switches between these receptors and intracellular signaling pathways. Of the four major families of $\mathrm{G}$ proteins (classified after their $\alpha$ subunits as $\mathrm{G} \alpha \mathrm{s}, \mathrm{G} \alpha \mathrm{O} / \mathrm{i}, \mathrm{G} \alpha \mathrm{q} / 11$ and $\mathrm{G} \alpha 12 / 13$ ), the regulation of the $\mathrm{G} \alpha 12 / 13$ proteins activity in the brain is the least understood. They can act as preferential effectors of the GPCRs coupling, typically to other $\mathrm{G} \alpha$ subunits, like in the case of $\alpha 1$-adrenergic receptors, muscarinic $\mathrm{M}_{1}$ or $\mathrm{M}_{3}$ receptor, or $5-\mathrm{HT}_{2 \mathrm{C}}$ serotonergic receptor [8] or provide a sole pathway for downstream signaling, like in the case of $5-\mathrm{HT}_{4}$ or $5-\mathrm{HT}_{7}$ serotonergic receptors [9]. Moreover, in vivo treatment with opioid receptor agonists or $5-\mathrm{HT}_{7}$ receptors antagonists may affect $\mathrm{G} \alpha 12 / 13$ mRNA expression [10-12].

Go12/13 proteins have been demonstrated to regulate various cellular processes via cooperation with Rho-family GTPases (e.g. RhoA, Rac1, or Cdc42), known as regulators of actin cytoskeleton remodeling [13, 14]. In neurons, Rho-GTPases modulate dendritic reorganization, including dynamic alterations of dendritic spines, which are crucial elements of synaptic plasticity $[15,16]$. In particular, RhoA and Rac1, the best known Rho-GTPases, have been shown to influence neuronal morphology. RhoA contributes to dendritic arbor simplification, whereas Rac1 is primarily involved in the maintenance of dendritic spines and dendritic arborization [17].

Structural changes in neurons are among the most pronounced effects of stress and are probably a key sign of stressrelated pathology $[18,19]$. However, the molecular mechanisms involved in stress-induced brain neuroplastic changes are still poorly understood. Given the vital role of the proteins mentioned above in the regulation of neuronal morphology, this study aimed to investigate whether repetitive restraint stress (RS), known to induce morphological alterations [5, 20], influences Galpha 12/13 and Rho-GTPase cross-linked signaling proteins at the level of mRNA in the prefrontal cortex (PFC), hippocampus (HIP) and amygdala (AMY) in mice, and on the protein level in the rat HIP. Furthermore, the involvement of $\beta 1$ adrenergic receptors ( $\beta 1 \mathrm{AR}$ ) in the stress pathology and the therapeutic potential of $\beta 1 \mathrm{AR}$ blockade were analyzed.

\section{Materials and methods}

\section{Animals}

The experiments were performed on adult C57BL/6N male mice (12-week-old) and adult Wistar Han male rats weighting 343-425 g ( 1 day RS experiment) and 285-340 g (chronic RS). Animals (Charles River, Germany) were housed in standard conditions at room temperature $21 \pm 1{ }^{\circ} \mathrm{C}, 40-50 \%$ humidity, and $12 \mathrm{~h}$ light/dark cycle. Food and water were available ad libitum, except during immobilization applied to stressed groups.

All procedures were approved by the Local Ethical Commission for Animal Experiments at Maj Institute of Pharmacology, Polish Academy of Sciences in Krakow (Permit number for the experiment involving mice: 789, 30.09.2010, and Permit number for the study on rats: 1106, 22.07.2014) and fulfilled the requirements of the EU Directive 2010/63/ EU on the protection of animals used for scientific purposes.

\section{Stress procedure}

Animals were randomly assigned to experimental groups. Stress procedure was performed in light phase of light/dark cycle. The mice from the stress group were restrained in well-ventilated polypropylene conical tubes $(50 \mathrm{ml})$ for $2 \mathrm{~h}$ daily for 14 consecutive days. In rats, the 1-day stress paradigm consisted of $3 \mathrm{~h}$ daily of RS, while in the case of chronic stress exposure, RS was applied for $4 \mathrm{~h}$ daily in the first 2 days and $3 \mathrm{~h}$ in the next 12 days. The rats were placed in perforated plastic tubes $(6.5 \mathrm{~cm}$ inner diameter $)$ of adjustable length. The restraint allowed breathing and limited movements of the head and limbs. After the stress procedure, animals were removed from the restrainers and returned to their home cages. Control (sham) animals were held in their home cages during the stress sessions.

\section{Betaxolol treatment protocol}

To assess the role of $\beta 1 \mathrm{AR}$ in the studied mechanism and to analyze the therapeutic effect of its inhibition, rats were treated with betaxolol (Alcon, Fort Worth, TX, USA). In the experiment with the 1-day RS paradigm, four groups were generated: sham/SAL $(n=7)$; RS/SAL $(n=7)$; sham/BET $(n=6) ; \mathrm{RS} / \mathrm{BET}(n=6)$. In these groups, 'RS' and 'sham' procedures were applied once, as described in the previous section. Animals received single oral administration ( $p o$, per os) of betaxolol ( $5 \mathrm{mg} / \mathrm{kg} / \mathrm{po}$ ) ('BET' groups) or $0.9 \% \mathrm{NaCl}$ $(0.5 \mathrm{ml} / \mathrm{rat})$ ('SAL' groups).

In the experiment with chronic RS, separate four animal groups were generated: sham/SAL $(n=7)$; RS/SAL $(n=7)$; sham/BET $(n=5)$; RS/BET $(n=5)$. In these groups, 'RS' and 'sham' procedures were applied repeatedly for 14 days, as described earlier. In the 2 nd week of RS procedure, immediately after stress, the treatment with betaxolol $(5 \mathrm{mg} /$ $\mathrm{kg} / \mathrm{po})$ or $0.9 \% \mathrm{NaCl}(0.5 \mathrm{ml} / \mathrm{rat} / \mathrm{po})$ was introduced for 'BET' and 'SAL' groups, respectively. Rats were treated for 7 consecutive days, from 8 to 14th experimental day. Dose and route of treatment were chosen based on the literature 
[21] and own preliminary results showing that the treatment protocol had no sedative effect on rats (measured by locomotor activity) and reversed the impact of chronic RS on the rats' body weight.

\section{Tissues}

All animals were decapitated $24 \mathrm{~h}$ after the last stress session. For the purpose of mRNA study the HIP, PFC and AMY were isolated from excised mouse brains, rapidly immersed in $500 \mu 1$ of RNAlater ${ }^{\circledR}$ (Ambion, USA) and stored first at $4{ }^{\circ} \mathrm{C}$ for $24 \mathrm{~h}$ and then at $-20{ }^{\circ} \mathrm{C}$ until further processing. To assess the protein expression, the HIP was isolated on an ice-cold glass plate, immediately frozen on dry ice and stored at $-70{ }^{\circ} \mathrm{C}$ until assayed.

\section{RNA isolation and RT-qPCR}

Total RNA was isolated from the brain tissue using the RNAeasy Mini Kit (Qiagen, Germany) according to the manufacturer's protocol. The quantity of RNA was determined spectrophotometrically using a NanoPhotometer ${ }^{\circledR}$ (IMPLEN, Germany) at $260 \mathrm{~nm}$. The quality of RNA was assessed based on the $260 \mathrm{~nm} / 280 \mathrm{~nm}$ absorbance ratio. Samples of total RNA ( $1 \mu \mathrm{g} /$ reaction) were reverse transcribed (RT) to cDNA using the High-Capacity cDNA Reverse Transcription Kit (Applied Biosystems, USA) in a final volume of $20 \mu \mathrm{l}$ for $2 \mathrm{~h}$ at $37^{\circ} \mathrm{C}$. mRNA expression levels of $\mathrm{G} \alpha 12, \mathrm{G} \alpha 13$, Rac1 and RhoA were assessed using quantitative PCR (qPCR) with TaqMan ${ }^{\circledR}$ probes (Gnal2 Mm00494665_m1, Gnal3 Mm00494667_ml, Rac1 Mm01201657_g1, RhoA Mm01601614_g1; Applied Biosystems, USA). The PCR reaction mix consisted of $50 \mathrm{ng}$ of cDNA, $1 \mu \mathrm{l}$ of a specific probe, $10 \mu \mathrm{l}$ of ready-touse FastStart Universal Probe Master (ROX) mix (Roche, Germany), and water to a final volume of $20 \mu 1$. The qPCR reaction was run in a Chromo4 Real-Time PCR Instrument (MJ Research, USA) with the following thermocycler protocol: $95{ }^{\circ} \mathrm{C} / 10 \mathrm{~min}$ activation step, followed by 40 cycles of $95^{\circ} \mathrm{C} / 15 \mathrm{~s}$ denaturation and $60{ }^{\circ} \mathrm{C} / 1 \mathrm{~min}$ for amplification and quantification. The qPCR reaction for each sample was prepared in two technical replicates. The cycle threshold value $(\mathrm{Ct})$ for each gene of interest was set in the PCR's exponential phase. Samples were analyzed for relative gene expression using the $\Delta \Delta \mathrm{Ct}$ method and normalized to beta-2 microglobulin ( $\mathrm{B2} \mathrm{m}, \mathrm{Mm00437762 \_ ml)}$ ) as an internal control.

\section{Protein isolation and immunoblotting}

Total protein was extracted through high-speed shaking in plastic tubes with stainless-steel beads in a tissue lyser with $100 \mu \mathrm{l}$ ice-cold RIPA lysis buffer (Sigma, USA) containing a complete mini protease inhibitor (Roche Diagnostics, USA). After incubation for $30 \mathrm{~min}$, the homogenates were centrifuged at $10,000 \times g$ for $20 \mathrm{~min}$ at $4{ }^{\circ} \mathrm{C}$. The resulting supernatants were collected and subjected to protein analysis using the Bicinchoninic Acid Assay Kit (Sigma, USA). Next, the standard Western blot procedure was conducted, as previously described [22]. Briefly, equal amounts of protein extracts $(6-20 \mu \mathrm{g})$ were boiled in Laemmli buffer containing $5 \% \beta$-mercaptoethanol for $5 \mathrm{~min}$, separated through SDSPAGE (4-15\%) and transferred to nitrocellulose membranes. The membranes were blocked with 5\% nonfat dry milk in Tris-buffered saline containing Tween-20 (TBST; $\mathrm{pH}=7.6$ ) for $1 \mathrm{~h}$ at room temperature and incubated with one type

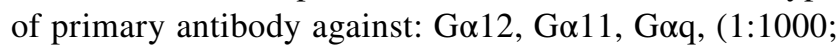
Santa Cruz Biotechnology, Dallas, TX, USA), RhoA, RhoB, RhoC, Rac1/2/3 (1:1000; Cell Signaling Technology, Danvers, MA, USA), overnight at $4{ }^{\circ} \mathrm{C}$. After three washes with the blocking solution, the membranes were incubated with the appropriate secondary antibodies for $1 \mathrm{~h}$ at room temperature, followed by three washes with TBST. Antibody binding was detected using an enhanced chemiluminescence kit (ECL Plus, Pierce, USA). Equal loading of protein per sample was further confirmed after probing with anti-calnexin (CNX) antiserum (1:5000; ADI-SPA-865-F, Enzo Life Sciences, USA). All Western blot analyses were performed at least twice to confirm the results. The chemiluminescence signal was visualized using a Luminescent Image Analyzer Fuji-Las 4000 (Fuji, Japan). Immunoreactive bands were quantified using an image analyzer (ScienceLab, MultiGauge V3.0).

\section{Data analysis}

All presented values were averaged from 5 to 8 animals \pm the standard error of the mean (SEM). The mRNA data were analyzed by a one-way analysis of variance (ANOVA) followed by Fisher's Least Significant Difference (LSD) test, while the protein data by a two-way ANOVA followed by unequal N HSD test using the Statistica 10.0 software (Round Rock, TX, USA). Analyzed results were considered statistically significant when $p<0.05$.

\section{Results}

\section{The effects of repeated restraint stress on the mRNA expression of $\mathrm{Ga12}, \mathrm{Ga13}$, RhoA, Rac in the mouse PFC, AMY and HIP}

Chronic restraint stress-evoked changes in mRNA expression of the analyzed genes that were differently pronounced among the brain regions considered (Fig. 1). In the PFC, compared to the control group, mRNA levels 
of $\mathrm{G} \alpha 12$ were decreased by $25 \%\left[F_{1,13}=8.33, p<0.05\right]$, while Rac1 increased by $83 \%\left[F_{1,12}=27.94, p<0.001\right]$.

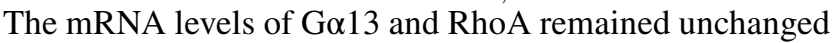

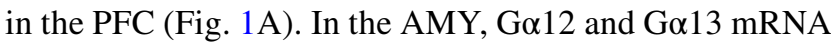
levels were reduced by $45 \%\left[F_{1,13}=76.79, p<0.001\right]$ and $17 \%\left[F_{1,13}=10.37, p<0.01\right]$, respectively. Moreover, in this brain structure, chronic RS reduced the RhoA mRNA levels by $35 \%$, compared to the control $\left[F_{1,12}=5.82\right.$, $p<0.05]$, while Rac1 mRNA levels were not affected by chronic RS in the AMY (Fig. 1B). No changes in mRNA expression were found in the HIP (Fig. 1C).
A

Ga12

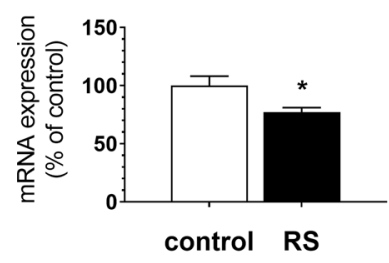

B

Ga12

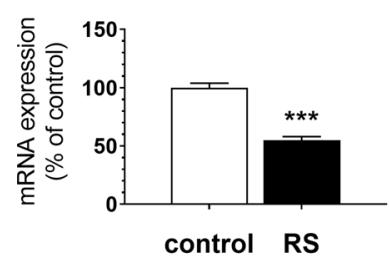

C
Ga13

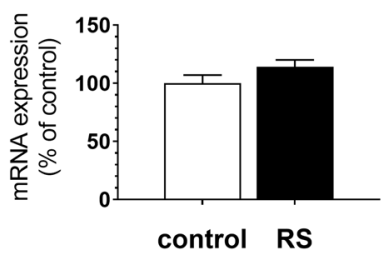

Amygdala
RhoA

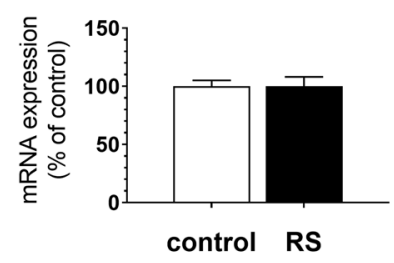

control RS
Rac1

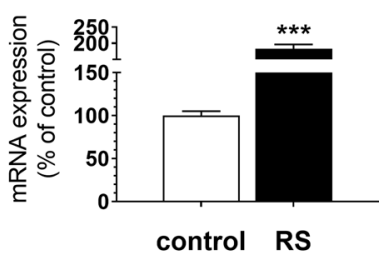

RhoA

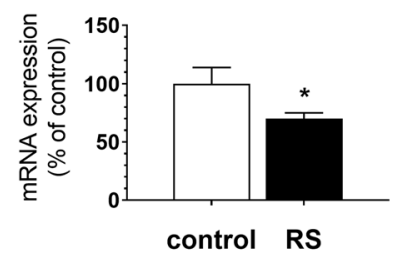

control RS
Rac1

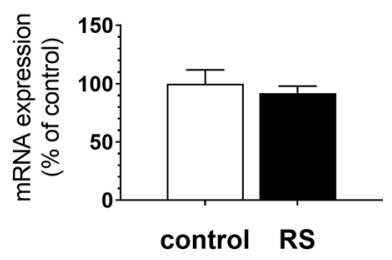

\section{Hippocampus}

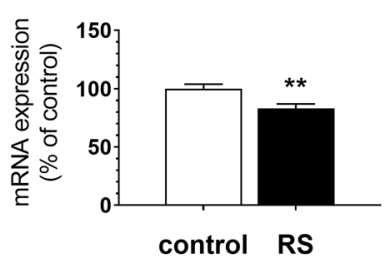

Ga12

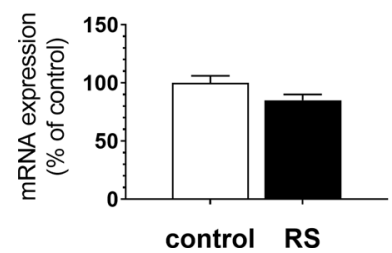

Ga13

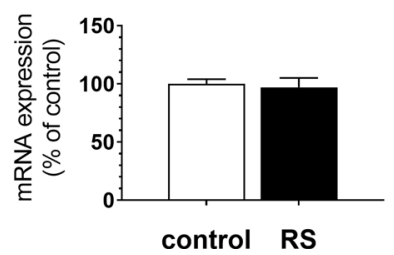

Fig. 1 The effects of chronic restraint stress (RS) on the mRNA expression of $\mathrm{G} \alpha 12 / 13$ and RhoA/Rac1 proteins in the mouse prefrontal cortex (A), amygdala $(\mathbf{B})$ and hippocampus $(\mathbf{C})$. The results of a one-way ANOVA for the RS effects on $\mathrm{G} \alpha 12\left[F_{1,13}=8.33\right.$, $p=0.012]$, Rac1 $\left[F_{1,12}=27.94, p<0.001\right]$ in the PFC, and on $\mathrm{G} \alpha 12\left[F_{1,13}=76.79, p<0.0001\right], \mathrm{G} \alpha 13 \quad\left[F_{1,13}=10.37, p=0.006\right]$,
RhoA

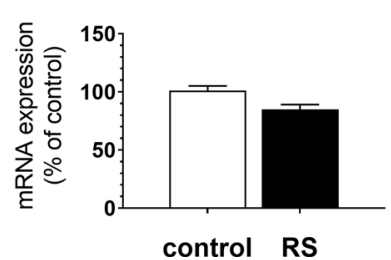

Rac1

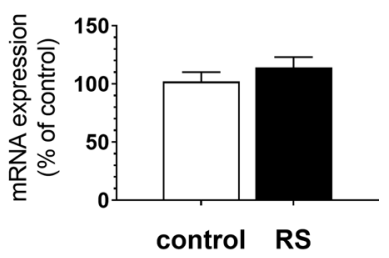

RhoA $\left[F_{1,12}=5.82, p=0.03\right]$ in the AMY. The bars represent the mean \pm SEM. Group sizes: PFC: $n=6$ (control) and $n=8$ (RS); AMY: $n=7$ (control) and $n=7$ (RS); HIP: $n=7$ (control) and $n=8$ (RS). $* p<0.05, * * p<0.01, * * * p<0.001$ vs control group (Fischer's LSD test) 


\section{The effect of stress and its modulation by betaxolol on the GTPase protein expression in the rat HIP}

\section{RhoA}

A two-way ANOVA revealed lack of influence of single RS $\left[F_{1,20}=0.07 ; p=0.80\right]$ and interaction of single $\mathrm{RS} \times$ single BET $\left[F_{1,20}=0.03 ; p=0.58\right]$ on the RhoA protein expression in the rat HIP (Fig. 2A). However, chronic RS increased RhoA expression by $86 \%$ vs sham/SAL group. The level of RhoA protein increased by chronic RS exposure was normalized when rats received BET in the 2nd week of RS procedure immediately after RS procedure (Fig. 2B). A two-way ANOVA (considering chronic RS-RS 14 days, sham and pharmacological treatment-SAL, BET-as independent factors) used to analyze RhoA levels showed significant effects of RS 14 days $\left[F_{1,18}=9.14 ; p<0.01\right]$ and RS 14 days $\times$ BET interaction: $\left[F_{1,18}=6.25 ; p<0.05\right]$. An unequal $N$ HSD test revealed a higher level of RhoA in the chronic RS/sham group in comparison to other groups: sham/SAL $(p<0.01)$, sham/BET $(p<0.05)$ and chronic RS/BET $(p<0.05)$. Betaxolol did not change RhoA expression in the rat HIP after single $\left[F_{1,20}=0.65 ; p=0.43\right]$ and repeated treatment $\left[F_{1,18}=3.57 ; p=0.07\right]$ (Fig. 2).

Ga12, Ga11, Gaq, RhoB, RhoC, Rac1/2/3 No differences among groups were observed in the protein levels of $\mathrm{G} \alpha 12$, G $\alpha 11$, G $\alpha$, RhoB, RhoC, Rac1/2/3 in the rat HIP after single and chronic exposure to RS and BET treatment (Table 1; Suppl. Tab. 1; Fig. 3).

A

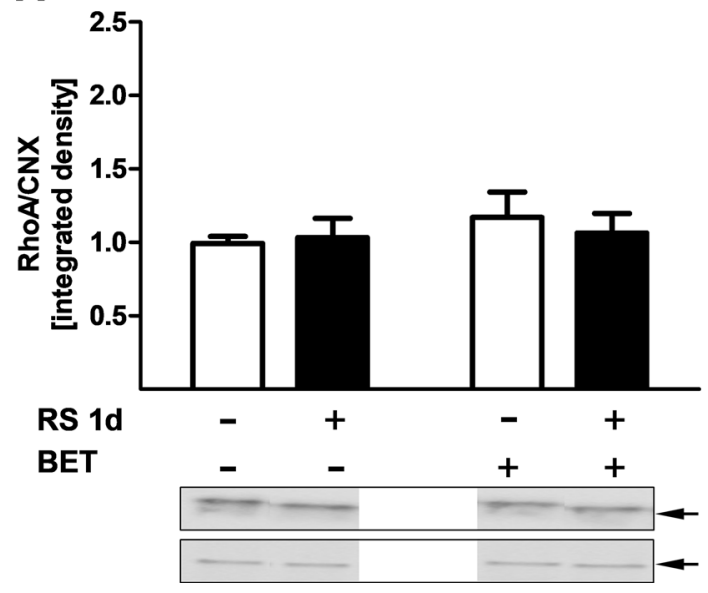

Fig. 2 The effects of single (A) and chronic (B) restraint stress (RS) and betaxolol (BET) $(5 \mathrm{mg} / \mathrm{kg} / \mathrm{po})$ post-stress treatment on the protein expression of RhoA in the rat hippocampus. The bars represent the mean \pm SEM. In A: single RS effect $[F(1,20)=0.07 ; p=0.80]$; single BET effect $[F(1,20)=0.65 ; p=0.43]$; single RS $\times$ single BET interaction $[F(1,20)=0.03 ; p=0.58] ; n=6 /$ each group. In $\mathbf{B}$ : RS effect

\section{Discussion}

Here, we have presented the analyses of the influence of repeated RS on the expression of genes coding for $\mathrm{G} \alpha 12 / 13$ and Rho-GTPases in the PFC, AMY and HIP of mice, and the stress-induced effects on the expression of intracellular proteins related to the $\mathrm{G} \alpha 12 / 13$ signaling pathway in the rats HIP. In the latter case, we showed that repeated RS caused an increase in the RhoA level, that was normalized by betaxolol applied immediately after the stress procedure.

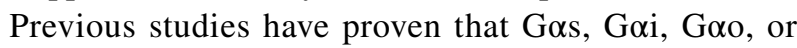
$\mathrm{G} \alpha \mathrm{q} / 11$ are engaged in the response to chronic stress or corticosterone administration [23-25]. In the current study, we found that repeated RS applied for $2 \mathrm{~h}$ daily decreased

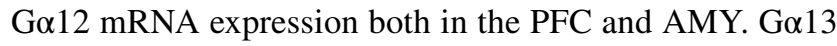
expression, in turn, was reduced exclusively in the AMY, and none of the genes exhibited differential expression in the HIP after repeated restraint stress in mice. The discrepancy between the effects of stress on G $\alpha 12$ and $\mathrm{G} \alpha 13$ mRNA expression is somewhat unexpected, as previous experiments using dominant active forms of $\mathrm{G} \alpha 12$ and $\mathrm{G} \alpha 13$ have demonstrated that these proteins signal through similar downstream effectors and, thus, likely have overlapping functions [26]. Nevertheless, studies have documented functional differences between these proteins by showing that $\mathrm{G} \alpha 13$ knock-out mice die in the uterus during embryonic development, while Go12 knock-out mice exhibit almost no abnormalities [27]. What is more, a previous study indicating the differential distribution of $\mathrm{G} \alpha 12$ and $\mathrm{G} \alpha 13$ within neuronal cells (i.e. Go12 localized in somata and neurites, whereas

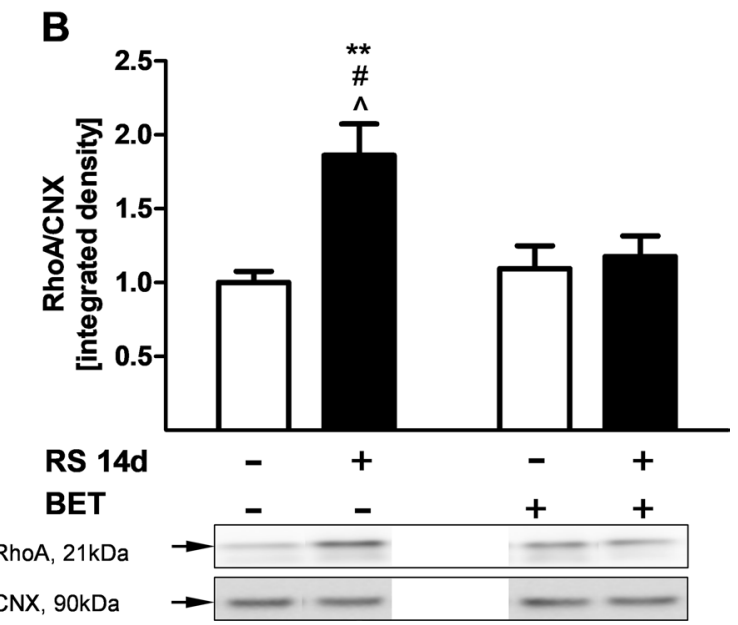

$[F(1,18)=9.14 ; p<0.01] ;$ BET effect $[F(1,18)=3.57 ; p=0.07]$ RS $\times$ BET interaction $[F(1,18)=6.25 ; p<0.05]$; group sizes: $n=6$ (sham/SAL); $n=5$ (sham/BET); $n=6$ (RS/SAL) $n=5$ (RS/BET). ${ }^{* *} p<0.01$ vs sham/SAL group; ${ }^{*} p<0.05$ vs sham/BET; ${ }^{\wedge} p<0.05$ vs RS/BET group (unequal N HSD test). CNX calnexin 
Table 1 Lack of single and repeated restraint stress effects and betaxolol treatment on the protein expression of $G \alpha(12), G \alpha(11), G \alpha(q), R h o B$, Rho C, Rac 1/2/3 in the rats' hippocampus

\begin{tabular}{|c|c|c|c|c|c|c|c|c|}
\hline \multirow{2}{*}{$\begin{array}{l}\text { Name of } \\
\text { protein }\end{array}$} & \multicolumn{4}{|c|}{ Acute restraint stress } & \multicolumn{4}{|c|}{ Chronic restraint stress } \\
\hline & sham/SAL & $\mathrm{RS} / \mathrm{SAL}$ & sham/BET & $\mathrm{RS} / \mathrm{BET}$ & sham/SAL & RS/SAL & sham/BET & RS/BET \\
\hline $\mathrm{G} \alpha(12)$ & $\begin{array}{l}1.00 \pm 0.11 \\
n=6\end{array}$ & $\begin{array}{l}0.79 \pm 0.18 \\
n=7\end{array}$ & $\begin{array}{l}0.98 \pm 0.10 \\
n=5\end{array}$ & $\begin{array}{l}0.96 \pm 0.20 \\
n=5\end{array}$ & $\begin{array}{l}0.97 \pm 0.07 \\
n=6\end{array}$ & $\begin{array}{l}1.13 \pm 0.07 \\
n=6\end{array}$ & $\begin{array}{l}1.04 \pm 0.05 \\
n=6\end{array}$ & $\begin{array}{l}1.08 \pm 0.05 \\
n=6\end{array}$ \\
\hline $\mathrm{G} \alpha(11)$ & $\begin{array}{l}1.04 \pm 0.11 \\
n=6\end{array}$ & $\begin{array}{l}1.01 \pm 0.11 \\
n=7\end{array}$ & $\begin{array}{l}1.05 \pm 0.17 \\
n=5\end{array}$ & $\begin{array}{l}1.10 \pm 0.14 \\
n=5\end{array}$ & $\begin{array}{l}1.02 \pm 0.07 \\
n=5\end{array}$ & $\begin{array}{l}0.94 \pm 0.21 \\
n=5\end{array}$ & $\begin{array}{l}1.07 \pm 0.14 \\
n=6\end{array}$ & $\begin{array}{l}1.22 \pm 0.18 \\
n=5\end{array}$ \\
\hline $\mathrm{G} \alpha(\mathrm{q})$ & $\begin{array}{l}1.01 \pm 0.07 \\
n=7\end{array}$ & $\begin{array}{l}1.39 \pm 0.26 \\
n=7\end{array}$ & $\begin{array}{l}1.07 \pm 0.10 \\
n=5\end{array}$ & $\begin{array}{l}1.20 \pm 0.11 \\
n=5\end{array}$ & $\begin{array}{l}0.99 \pm 0.08 \\
n=6\end{array}$ & $\begin{array}{l}0.79 \pm 0.06 \\
n=6\end{array}$ & $\begin{array}{l}0.92 \pm 0.10 \\
n=6\end{array}$ & $\begin{array}{l}0.98 \pm 0.08 \\
n=6\end{array}$ \\
\hline Rho B & $\begin{array}{l}1.01 \pm 0.12 \\
n=6\end{array}$ & $\begin{array}{l}1.23 \pm 0.26 \\
n=6\end{array}$ & $\begin{array}{l}0.94 \pm 0.13 \\
n=6\end{array}$ & $\begin{array}{l}1.06 \pm 0.15 \\
n=6\end{array}$ & $\begin{array}{l}1.06 \pm 0.22 \\
n=7\end{array}$ & $\begin{array}{l}1.31 \pm 0.24 \\
n=7\end{array}$ & $\begin{array}{l}0.98 \pm 0.24 \\
n=5\end{array}$ & $\begin{array}{l}0.84 \pm 0.23 \\
n=5\end{array}$ \\
\hline Rho C & $\begin{array}{l}0.99 \pm 0.15 \\
n=6\end{array}$ & $\begin{array}{l}1.06 \pm 0.11 \\
n=6\end{array}$ & $\begin{array}{l}1.11 \pm 0.09 \\
n=6\end{array}$ & $\begin{array}{l}0.91 \pm 0.09 \\
n=6\end{array}$ & $\begin{array}{l}1.01 \pm 0.16 \\
n=6\end{array}$ & $\begin{array}{l}1.08 \pm 0.11 \\
n=6\end{array}$ & $\begin{array}{l}0.77 \pm 0.08 \\
n=5\end{array}$ & $\begin{array}{l}0.96 \pm 0.16 \\
n=5\end{array}$ \\
\hline $\operatorname{Rac} 1 / 2 / 3$ & $\begin{array}{l}1.03 \pm 0.10 \\
n=6\end{array}$ & $\begin{array}{l}1.15 \pm 0.11 \\
n=6\end{array}$ & $\begin{array}{l}1.11 \pm 0.12 \\
n=6\end{array}$ & $\begin{array}{l}1.15 \pm 0.21 \\
n=6\end{array}$ & $\begin{array}{l}0.98 \pm 0.11 \\
n=7\end{array}$ & $\begin{array}{l}1.18 \pm 0.11 \\
n=7\end{array}$ & $\begin{array}{l}0.99 \pm 0.07 \\
n=5\end{array}$ & $\begin{array}{l}1.18 \pm 0.18 \\
n=5\end{array}$ \\
\hline
\end{tabular}

The levels of indicated proteins were analyzed with Western Blot method. Data were calculated as percentages of controls and are expressed as means \pm SEM

$R S$ restraint stress, $B E T$ betaxolol, $S A L$ saline control

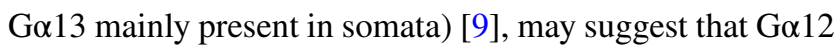
rather than $\mathrm{G} \alpha 13$ is engaged in synaptic remodeling. Proteins RhoA and Rac1 are representatives of the Rho-like and Rac-like families, two subfamilies of the Rho-family proteins. The limited studies concerning the role of Rho-family proteins in psychiatric disorders suggested that Rho-like and Rac-like subfamilies are involved in the pathomechanisms of schizophrenia, addiction and depression [28]. In our study, chronic RS in mice increased Rac1 mRNA expression in the PFC and decreased RhoA expression in the AMY.

All Rho-family proteins are downstream effectors of receptors coupled to $\mathrm{G} \alpha 12 / 13$ [29] and the expression of both heterotrimeric $G$ proteins and small GTPases in response to chronic RS was simultaneously decreased in the AMY. However, in the PFC, the expression of Rac1 was increased, while G $\alpha 12$ decreased. A possible explanation why Go12 and Rac1 mRNA expression levels changed in opposite directions after restraint stress in the PFC may be based on likely interactions between $\mathrm{G} \alpha 12 / 13$ and $\mathrm{G} \alpha q / 11$ protein families [30, 30]. Rac1, in some instances, may be activated as a second messenger downstream of other $G$ proteins, like Gq. Simultaneously, RhoA is generally the direct target of Go12/13 [30], what explains why in the AMY decreases in the expression of RhoA and Go12/13 were noted. No changes in mRNA expression were observed in the mice HIP. In contrast to our results, a previous in vitro study determined that treating amygdaloid and hippocampal cell lines with corticosterone results in increased RhoA mRNA levels but does not affect Rac1 expression [31]. However, this earlier study involved modeling stress by incubating cells with corticosterone for $24 \mathrm{~h}$, which likely mimicked acute stress rather than chronic one. Nevertheless, in vitro or even in vivo corticosterone treatment probably does not fully reflect the myriad of different substances that can affect brain structure-function during stress treatment [32]. On the other hand, a previous study found decreased Rac1 mRNA expression in the nucleus accumbens of depressed patients and chronically stressed mice [28]. The lack of differential mRNA expression in the HIP we revealed in our study has been an intriguing issue. This structure has been recognized as a gateway to remodel brain structure and function by exposure to stress hormones [33].

Some data show that periods of stress shorter than 21 days are not sufficient to cause dendritic spines retraction in the HIP [34]. Moreover, Alfonso et al. [25] showed that the HIP stress caused altered expression of genes coding for molecules regulating neurite outgrowth, like NGF, BDNF, G $\alpha$, after exposure to stress procedure more severe than $2 \mathrm{~h}$ daily. Indeed, when we applied chronic but not acute RS in rats for 3-4 h daily, we observed an increase of RhoA protein expression in the HIP. Rho-GTPases RhoA, RhoB, RhoC are ubiquitously expressed in mammals and possess $87 \%$ amino acid sequence identity; however, they have specific and pleiotropic intracellular functions [35]. In our study, chronic RS in rats upregulated only RhoA level. Our observation stays in agreement with the data showing high activation of RhoA in mice hippocampal slices exposed to corticotropin-releasing hormone (CRH) [36]. Similarly, it is significant that augmented RhoA activity was implicated in the mechanism of stress-evoked spine loss in dendrites of CA1 pyramidal neurons and was accompanied by LTP disturbance. Moreover, the authors revealed that other members of the Rho family of small GTPases are less affected by exposure to stress, what can explain the lack of RS-evoked 


\section{Acute Restraint Stress Chronic Restraint Stress}
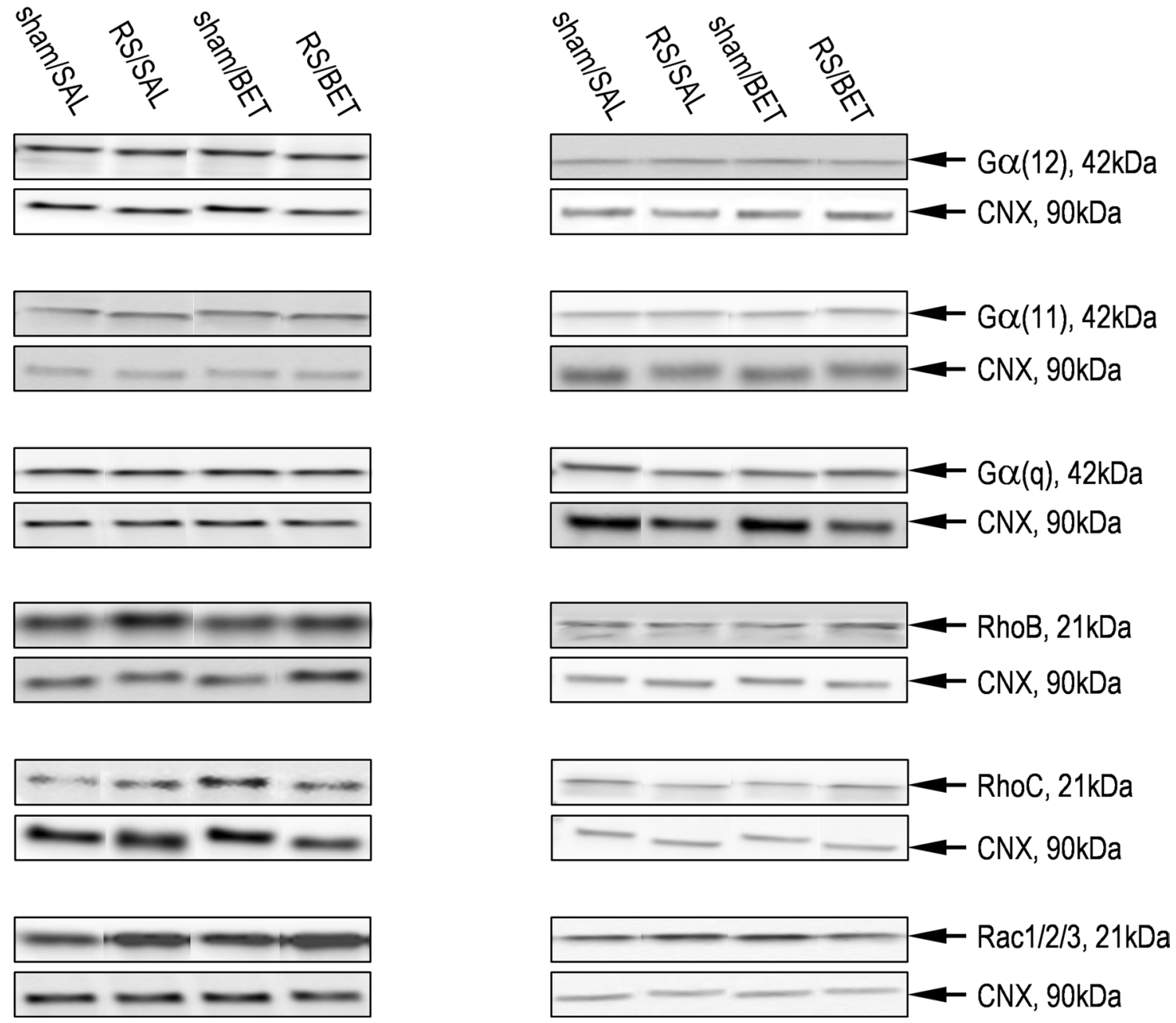

Fig. 3 Representative immunoblots that illustrate protein expression of $\mathrm{G} \alpha(12), \mathrm{G} \alpha(11), \mathrm{G} \alpha(\mathrm{q})$, RhoB, RhoC, and Rac1/2/3 in the rat HIP. Left columns - effects of single RS and BET treatment. Right columns-effects of chronic RS and BET treatment. For other descriptions, see Fig. 2

changes we obtained in the expression of RhoB, RhoC and Rac proteins. In the HIP, the signaling proteins upstream to RhoA: G $\alpha 12$ and cooperating with $\mathrm{G} \alpha \mathrm{q}$ and $\mathrm{G} \alpha 11$, were not affected by stress in our study, suggesting that activation of $\mathrm{G} \alpha 12 / 13$-coupled receptors is not involved in the stress response in the rat hippocampus cells.

In our study, repeated RS resulted in the increase of RhoA protein level in the HIP of rats, while no change was observed in mRNA expression of the gene encoding for this protein in mice. The exact reason for the discrepancy between the effect of RS on RhoA mRNA and the RhoA protein level in the HIP of these two species is not clear. However, there a few arguments that seem plausible. First of all, it is known that the mRNA rate or degree of expression of a given gene does not necessarily reflect its protein expression level. Also, it is estimated that the protein expression level of only about one-third of proteins correlates with the level of their mRNA expression (when measured at the same time point). Both processes, the gene transcription and translation to protein, are subject to multi-level and complex regulations. In certain circumstances, the mRNA degradation may be enhanced to maintain mRNA homeostatic turnover. Thus, $24 \mathrm{~h}$ after the last stress session, when the brain tissue was isolated, the mRNA changes might be poorly detectable.

We are aware that our experimental approach has some limitations regarding the use of different species, i.e. mice and rats. Though both species are commonly used laboratory animals, their genetic diversity should be borne in mind. Furthermore, the regulation of gene expression depends indirectly on the activity of neural circuits. A certain difference between mice and rats may exist in the organization of brain circuits' connectivity. For instance, Scheel 
et al. [37] described the interspecies differences regarding the integration of the nucleus reuniens (a part of the midline thalamus) in circuits of fear, aversion, and defense. The brain stress systems in rats and mice operate on the same bases, and across species there is some universal consistency with respect to brain regions expressing high levels of mineralocorticoid (MR) and glucocorticoid (GR) receptors in adulthood [38, 39]. However, these two species exhibit differences in the ontogenetic profiles of average MR and GR expression levels that may result in differential susceptibility to stress in adulthood [39].

We have shown for the first time that pharmacotherapy with betaxolol, the $\beta 1 \mathrm{AR}$ blocker, normalized the stressevoked increase of RhoA level in the rat HIP. The $\beta 1 \mathrm{AR}$ are anatomically and functionally predisposed to respond to high noradrenaline concentration released during stress in the HIP. Therefore, these receptors could be implicated in stress-related plasticity. Immunohistochemistry revealed dense expression of $\beta 1 \mathrm{AR}$ in the HIP [40]. Electrophysiological studies showed their modulatory role in LTP occurrence in the HIP [41]. Betaxolol also alleviated stress symptoms in preclinical and clinical studies [21, 41]. However, the intracellular mechanism of plasticity in the hippocampus with $\beta 1 \mathrm{AR}$ involvement remains unknown. One possibility is a direct coupling of $\beta 1 A R$ to G12/13, what has been recently suggested as a novel signaling pathway [42].

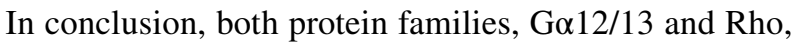
were previously shown to be associated with brain neuroplasticity during nonpathological conditions $[17,30]$. Our results suggest that these proteins are engaged in the mechanism of stress-related pathological changes in dendritic spines, as observed in other studies [5, 36, 43]. We have proven that betaxolol normalized the chronic stress-induced upregulation of RhoA in the HIP, indicating therapeutic usefulness of $\beta 1 \mathrm{AR}$ blockade in reversing stress-related disturbance of synaptic function and plasticity.

Supplementary Information The online version contains supplementary material available at https://doi.org/10.1007/s43440-021-00294-4.

Author contributions All authors have contributed significantly to the work and have read and approved the manuscript for publication. AZM and IN conceptualized and designed the study. KRZ, BT, PCh and GK conducted experiments. KRZ, BT and AZM performed data analysis. $\mathrm{KRZ}, \mathrm{AZM}, \mathrm{MW}$ and IN wrote or contributed to the writing of the manuscript. IN supervised the study and funding acquisition.

Funding This study was supported by statutory funds from the Institute of Pharmacology, Polish Academy of Sciences and by the Grant No. POIG.01.01.02-12-004/09-00, task no. 1.4 financed by the European Regional Development Fund.

\section{Declarations}

Conflicts of interest The authors declare no conflicts of interest.
Open Access This article is licensed under a Creative Commons Attribution 4.0 International License, which permits use, sharing, adaptation, distribution and reproduction in any medium or format, as long as you give appropriate credit to the original author(s) and the source, provide a link to the Creative Commons licence, and indicate if changes were made. The images or other third party material in this article are included in the article's Creative Commons licence, unless indicated otherwise in a credit line to the material. If material is not included in the article's Creative Commons licence and your intended use is not permitted by statutory regulation or exceeds the permitted use, you will need to obtain permission directly from the copyright holder. To view a copy of this licence, visit http://creativecommons.org/licenses/by/4.0/.

\section{References}

1. Anacker C, Scholz J, O'Donnell KJ, Allemang-Grand R, Diorio J, Bagot RC, et al. Neuroanatomic differences associated with stress susceptibility and resilience. Biol Psychiatry. 2016;79:840-9. https://doi.org/10.1016/j.biopsych.2015.08.009.

2. Kulkarni VA, Firestein BL. The dendritic tree and brain disorders. Mol Cell Neurosci. 2012;50:10-20. https://doi.org/10. 1016/j.men.2012.03.005.

3. Leuner B, Shors TJ. Stress, anxiety, and dendritic spines: what are the connections? Neuroscience. 2013;251:108-19. https:// doi.org/10.1016/j.neuroscience.2012.04.021.

4. Izquierdo A, Wellman CL, Holmes A. Brief uncontrollable stress causes dendritic retraction in infralimbic cortex and resistance to fear extinction in mice. J Neurosci. 2006;26:57338. https://doi.org/10.1523/JNEUROSCI.0474-06.2006.

5. Radley JJ, Sisti HM, Hao J, Rocher AB, McCall T, Hof PR, et al. Chronic behavioral stress induces apical dendritic reorganization in pyramidal neurons of the medial prefrontal cortex. Neuroscience. 2004;26:7870-4. https://doi.org/10.1016/j.neuro science.2004.01.006.

6. Dias-Ferreira E, Sousa JC, Melo I, Morgado P, Mesquita AR, Cerqueira JJ, et al. Chronic stress causes frontostriatal reorganization and affects decision-making. Science (80-). 2009;325:621-5. https://doi.org/10.1126/science.1171203.

7. Liston C, Miller MM, Goldwater DS, Radley JJ, Rocher AB, Hof PR, et al. Stress-induced alterations in prefrontal cortical dendritic morphology predict selective impairments in perceptual attentional set-shifting. J Neurosci. 2006;26:7870-4. https://doi.org/10.1523/JNEUROSCI.1184-06.2006.

8. Meigs TE, Lyakhovich A (2016) G Protein Alpha 12 and 13. In: Encycl Signal Mol, Springer, New York, p 1-15. https://doi.org/ 10.1007/978-1-4614-6438-9_586-1

9. Kvachnina E, Liu G, Dityatev A, Renner U, Dumuis A, Richter DW, et al. 5-HT7 receptor is coupled to G $\alpha$ subunits of heterotrimeric G12-protein to regulate gene transcription and neuronal morphology. J Neurosci. 2005;25:7821-30. https://doi.org/10. 1523/JNEUROSCI.1790-05.2005.

10. Nalepa I, Zelek-Molik A, Bielawski A, Roman A, Vetulani J. Does the presence of morphine counteract adaptive changes in expression of G-protein $\alpha$ subunits mRNA induced by chronic morphine treatment? Pharmacol Rep. 2007;59:34-45.

11. Zelek-Molik A, Bielawski A, Kreiner G, Popik P, Vetulani J, Nalepa I. Morphine-induced place preference affects mRNA expression of $\mathrm{G}$ protein $\alpha$ subunits in rat brain. Pharmacol Rep. 2012;64:546-57. https://doi.org/10.1016/S1734-1140(12) 70850-2.

12. Tokarski K, Zelek-Molik A, Duszyńska B, Satała G, Bobula B, Kusek M, et al. Acute and repeated treatment with the 5-HT7 receptor antagonist SB 269970 induces functional desensitization of 5-HT7 receptors in rat hippocampus. Pharmacol Rep. 
2012;64:256-65. https://doi.org/10.1016/S1734-1140(12) 70763-6.

13. Burridge $\mathrm{K}$, Wennerberg $\mathrm{K}$. Rho and Rac take center stage. Cell. 2004;116:167-79. https://doi.org/10.1016/S0092-8674(04) 00003-0.

14. Siehler S. Regulation of RhoGEF proteins by G 12/13-coupled receptors. Br J Pharmacol. 2009;158:41-9. https://doi.org/10. 1111/j.1476-5381.2009.00121.x.

15. Liu L, Luo M, Yang B, Wu X, Zhu W, Guan Y, et al. Actin-binding Rho activating protein is expressed in the central nervous system of normal adult rats. Neural Regen Res. 2012;7:965-70. https://doi.org/10.3969/j.issn.1673-5374.2012.13.001.

16. Sit ST, Manser E. Rho GTPases and their role in organizing the actin cytoskeleton. J Cell Sci. 2011;124:679-83. https://doi.org/ 10.1242/jcs.064964.

17. Nakahata Y, Yasuda R. Plasticity of spine structure: local signaling, translation and cytoskeletal reorganization. Front Synaptic Neurosci. 2018. https://doi.org/10.3389/fnsyn.2018.00029.

18. Licznerski P, Duman RS. Remodeling of axo-spinous synapses in the pathophysiology and treatment of depression. Neuroscience. 2013;251:33-50. https://doi.org/10.1016/j.neuroscience.2012.09. 057.

19. Pittenger C, Duman RS. Stress, depression, and neuroplasticity: a convergence of mechanisms. Neuropsychopharmacology. 2008;33:88-109. https://doi.org/10.1038/sj.npp.1301574.

20. Radley JJ, Rocher AB, Miller M, Janssen WGM, Liston C, Hof $\mathrm{PR}$, et al. Repeated stress induces dendritic spine loss in the rat medial prefrontal cortex. Cereb Cortex. 2006;16:313-20. https:// doi.org/10.1093/cercor/bhi104.

21. Rudoy CA, Van Bockstaele EJ. Betaxolol, a selective $\beta 1$-adrenergic receptor antagonist, diminishes anxiety-like behavior during early withdrawal from chronic cocaine administration in rats. Prog Neuro-Psychopharmacol Biol Psychiatry. 2007;31:1119-29. https://doi.org/10.1016/j.pnpbp.2007.04.005.

22. Sun WL, Zelek-Molik A, McGinty JF. Short and long access to cocaine self-administration activates tyrosine phosphatase STEP and attenuates GluN expression but differentially regulates GluA expression in the prefrontal cortex. Psychopharmacology. 2013;229:603-13. https://doi.org/10.1007/s00213-013-3118-5.

23. Okuhara DY, Beck SG, Muma NA. Corticosterone alters G protein $\alpha$-subunit levels in the rat hippocampus. Brain Res. 1997;745:144-51. https://doi.org/10.1016/S0006-8993(96) 01142-0.

24. Wolfgang D, Chen I, Wand GS. Effects of restraint stress on components of adenylyl cyclase signal transduction in the rat hippocampus. Neuropsychopharmacology. 1994;11:187-93. https:// doi.org/10.1038/sj.npp.1380105.

25. Alfonso J, Frick LR, Silberman DM, Palumbo ML, Genaro AM, Frasch AC. Regulation of hippocampal gene expression is conserved in two species subjected to different stressors and antidepressant treatments. Biol Psychiatry. 2006;59:244-51. https://doi. org/10.1016/j.biopsych.2005.06.036.

26. Gu JL, Müller S, Mancino V, Offermanns S, Simon MI. Interaction of $\mathrm{G} \alpha 12$ with $\mathrm{G} \alpha 13$ and $\mathrm{G} \alpha q$ signaling pathways. Proc Natl Acad Sci USA. 2002;99:9352-7. https://doi.org/10.1073/pnas. 102291599.

27. Moers A, Nürnberg A, Goebbels S, Wettschureck N, Offermanns S. G $\alpha 12 / G \alpha 13$ deficiency causes localized overmigration of neurons in the developing cerebral and cerebellar cortices. Mol Cell Biol. 2008;28:1480-8. https://doi.org/10.1128/mcb.00651-07.

28. Golden SA, Christoffel DJ, Heshmati M, Hodes GE, Magida $\mathrm{J}$, Davis K, et al. Epigenetic regulation of RAC1 induces synaptic remodeling in stress disorders and depression. Nat Med. 2013;19:337-44. https://doi.org/10.1038/nm.3090.
29. Yu OM, Brown JH. G protein-coupled receptor and RhoA-stimulated transcriptional responses: links to inflammation, differentiation, and cell proliferation. Mol Pharmacol. 2015;88:171-80. https://doi.org/10.1124/mol.115.097857.

30. Riobo NA, Manning DR. Receptors coupled to heterotrimeric G proteins of the G12 family. Trends Pharmacol Sci. 2005;26:14654. https://doi.org/10.1016/j.tips.2005.01.007.

31. Xu Y, Zhang C, Wang R, Govindarajan SS, Barish PA, Vernon $\mathrm{MM}$, et al. Corticosterone induced morphological changes of hippocampal and amygdaloid cell lines are dependent on 5-HT 7 receptor related signal pathway. Neuroscience. 2011;182:71-81. https://doi.org/10.1016/j.neuroscience.2011.02.042.

32. Gray JD, Rubin TG, Hunter RG, McEwen BS. Hippocampal gene expression changes underlying stress sensitization and recovery. Mol Psychiatry. 2014;19:1171-8. https://doi.org/10.1038/mp. 2013.175.

33. McEwen BS, Nasca C, Gray JD. Stress effects on neuronal structure: hippocampus, amygdala, and prefrontal cortex. Neuropsychopharmacology. 2016;41:3-23. https://doi.org/10.1038/npp. 2015.171.

34. Magariños AM, McEwen BS. Stress-induced atrophy of apical dendrites of hippocampal CA3c neurons: comparison of stressors. Neuroscience. 1995;69:83-8. https://doi.org/10.1016/03064522(95)00256-I.

35. Vega FM, Ridley AJ. The RhoB small GTPase in physiology and disease. Small GTPases. 2018;9:384-93. https://doi.org/10.1080/ 21541248.2016.1253528.

36. Chen Y, Kramár EA, Chen LY, Babayan AH, Andres AL, Gall $\mathrm{CM}$, et al. Impairment of synaptic plasticity by the stress mediator $\mathrm{CRH}$ involves selective destruction of thin dendritic spines via RhoA signaling. Mol Psychiatry. 2013;18:485-96. https://doi.org/ 10.1038/mp.2012.17.

37. Scheel N, Wulff P, de Mooij-van Malsen JG. Afferent connections of the thalamic nucleus reuniens in the mouse. J Comp Neurol. 2020;528:1189-202. https://doi.org/10.1002/cne.24811.

38. de Kloet ER, Joëls M, Holsboer F. Stress and the brain: from adaptation to disease. Nat Rev Neurosci. 2005;6:463-75. https:// doi.org/10.1038/nrn1683.

39. Pryce CR. Postnatal ontogeny of expression of the corticosteroid receptor genes in mammalian brains: inter-species and intraspecies differences. Brain Res Rev. 2008;57:596-605. https://doi. org/10.1016/j.brainresrev.2007.08.005.

40. Paschalis A, Churchill L, Marina N, Kasymov V, Gourine A, Ackland G. $\beta 1$-Adrenoceptor distribution in the rat brain: an immunohistochemical study. Neurosci Lett. 2009;458:84-8. https://doi. org/10.1016/j.neulet.2009.04.023.

41. Ramos BP, Arnsten AFT. Adrenergic pharmacology and cognition: focus on the prefrontal cortex. Pharmacol Ther. 2007;113:523-36. https://doi.org/10.1016/j.pharmthera.2006. 11.006.

42. Lukasheva V, Devost D, Le Gouill C, Namkung Y, Martin RD, Longpré JM, et al. Signal profiling of the $\beta 1$ AR reveals coupling to novel signalling pathways and distinct phenotypic responses mediated by $\beta 1 \mathrm{AR}$ and $\beta 2 \mathrm{AR}$. Sci Rep. 2020. https://doi.org/10. 1038/s41598-020-65636-3.

43. McEwen BS, Bowles NP, Gray JD, Hill MN, Hunter RG, Karatsoreos IN, et al. Mechanisms of stress in the brain. Nat Neurosci. 2015;18:1353-63. https://doi.org/10.1038/nn.4086.

Publisher's Note Springer Nature remains neutral with regard to jurisdictional claims in published maps and institutional affiliations. 